\title{
Evaluation of alternatives for flood irrigation and water usage in Spain under Mediterranean climate
}

\section{García-Garizábal ${ }^{a}$, , *}

ikerggarizabal@gmail.com

\section{J. Causapéb}

D. Merchán ${ }^{\text {, }}$,

aSpanish National Institute for Agricultural and Food Research and Technology (INIA), Ctra de la Coruña, Km 7,5, 28040 Madrid, Spain

'Instituto Geológico y Minero de España (IGME), C/Manuel Lasala n 44 9³., 50006 Zaragoza, Spain

Center of Alternative and Renewable Energy, Department of Renewable Energy Engineering, Federal University of Paraiba, Cx Postal 5115, 58051-900, João Pessoa, Paraiba, Brazil* Corresponding author.

${ }^{1}$-Independent researcher

\section{Abstract}

Evaluation of water management has been progressively more necessary to determine the availability of water resources, especially in the Mediterranean environment where competition for these resources is maximum

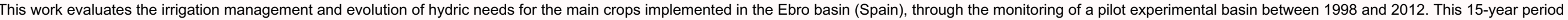
comprehends changes in irrigation implemented by the Irrigation District as well as climate and agronomic variabilities of the region.

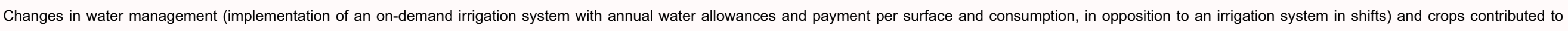

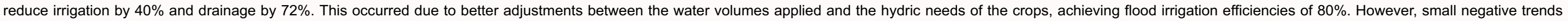
were detected in the water deficit evolution of corn and sunflower, which should be addressed and improved

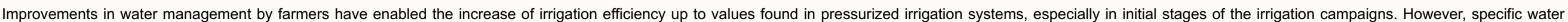
deficit episodes were detected that should be remediated.

Keywords: Irrigation water management; Irrigation efficiency; Water balance; Water deficit; Ebro river basin

\subsection{Introduction}

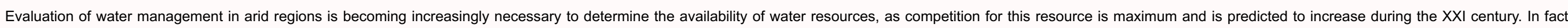

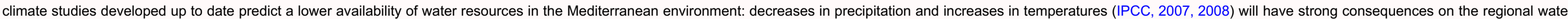
balance.

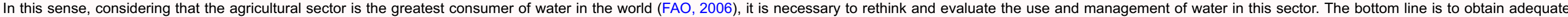
agrarian efficiencies without causing simultaneous negative impacts to the natural environment.

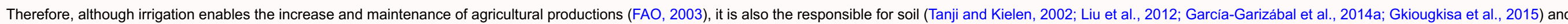

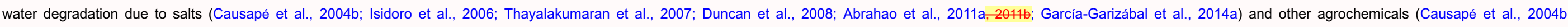

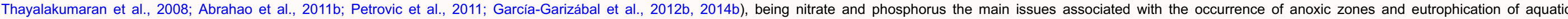
environments (Diaz, 2001; Scavia and Bricker, 2006; Wang, 2006). 


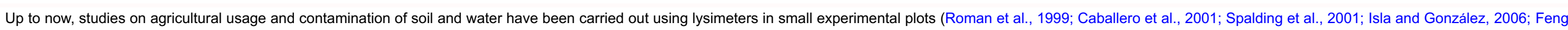

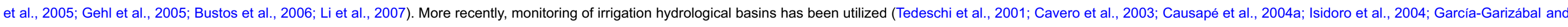
Causapé, 2010; Abrahao et al., 2011a; Barros et al., 2011; García-Garizábal et al., 2011), which is a methodology considered to be highly appropriate to evaluate water management at plot and irrigation district levels.

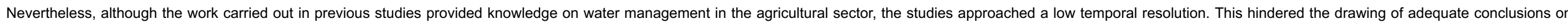
irrigation management for agricultural districts, mainly due to the high annual climate variability that exists in the Mediterranean area.

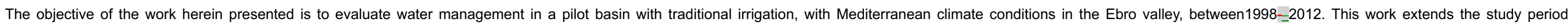
developed by García-Garizábal et al. (2011; 2001-2008) and better accommodates the climate and agronomic variabilities of the region.

\subsection{Description of the study zone}

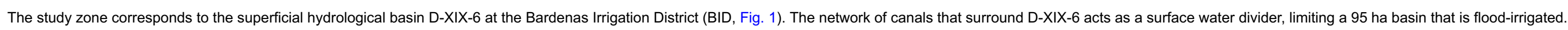
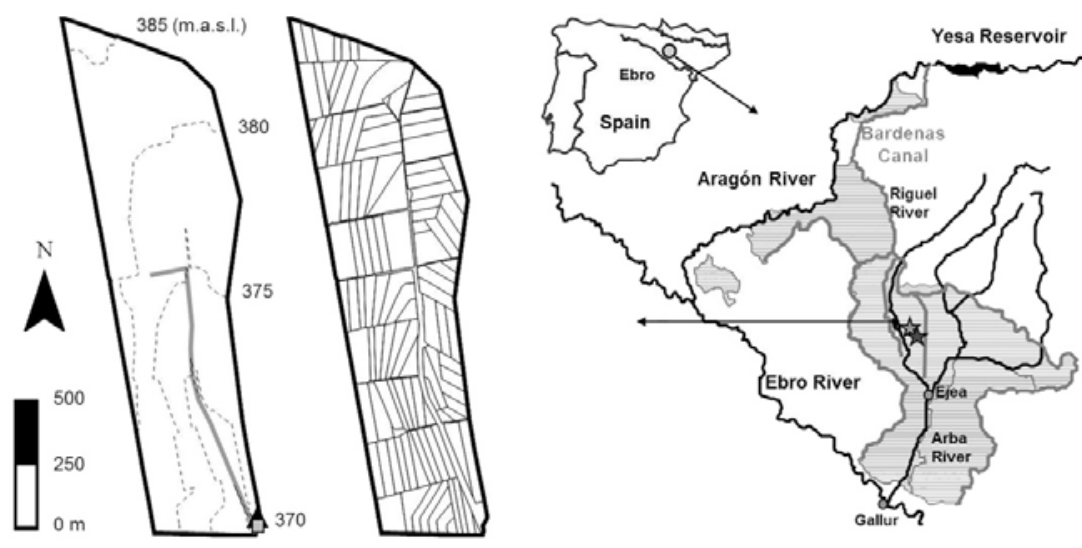

A Gauging $=$ Drainage ditch $\square$ Agricultural plot $\cdots$ Topography

Figure 1.Fig. 1 Location of the experimental basin D-XIX-6 within the Bardenas irrigation system and weather stations employed in the study.

alt-text: Fig. 1

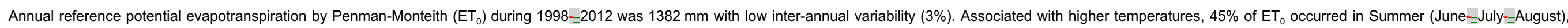
while only $9 \%$ of annual $\mathrm{ET}_{0} \mathrm{Occurred}$ in Winter (December-_January-=February; Fig. 2).

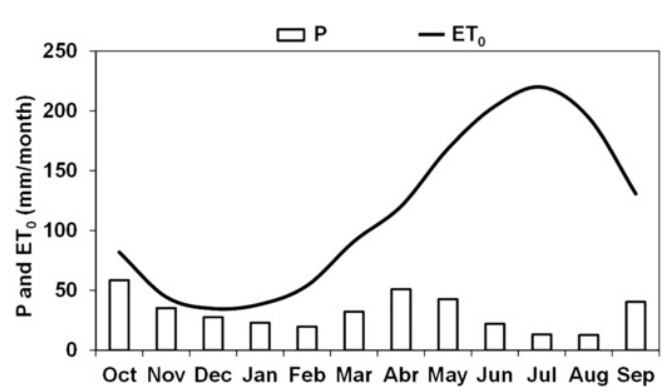

Figure 2.Fig. 2 Monthly average precipitation $(P)$ and reference evapotranspiration $\left(E T_{0}\right)$ values in the study zone, for the period 1998-2012.

alt-text: Fig. 2 


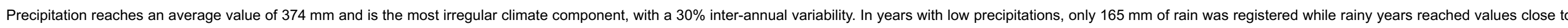
$600 \mathrm{~mm}$, with maximums in Spring_(March-_April-_May) and Autumn (September-_October-_November; Fig. 2).

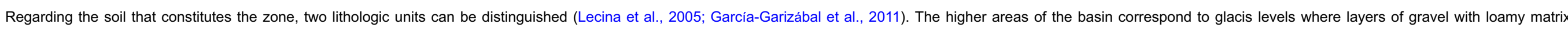
(11_43\%) develop with average water retention capacity of $111 \mathrm{~mm}$ (Calcixerollic Xerochrept).

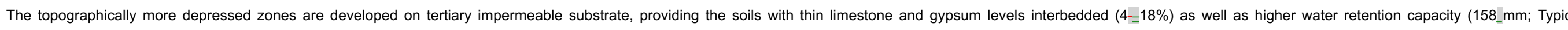
Xerofluvent).

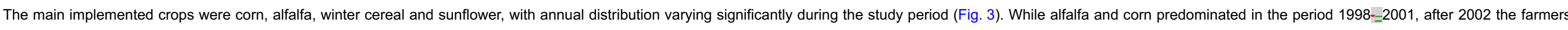
opted for crops with lower hydric needs such as winter cereal and sunflower.

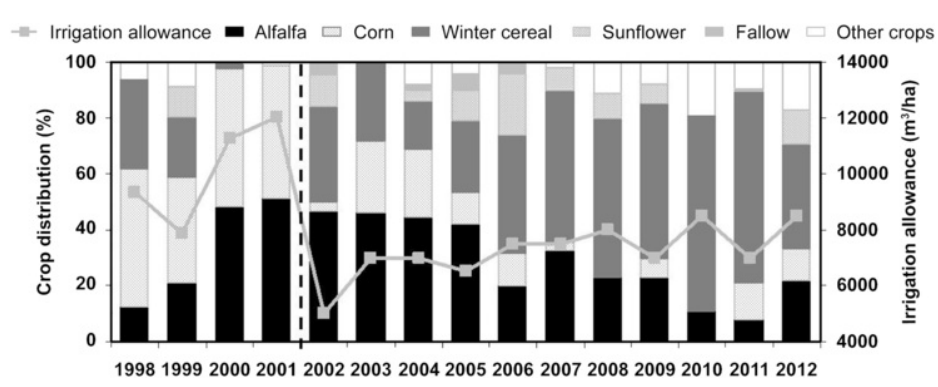

Figure 3.Fig. 3 Distribution (\%) of main crops and annual irrigation allowance $\left(\mathrm{m}^{3} / \mathrm{ha}\right)$ in basin D-XIX-6 during 1998--2012. Data on irrigation allowance provided by BID. alt-text: Fig. 3

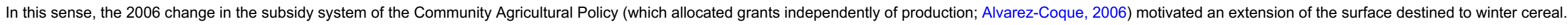

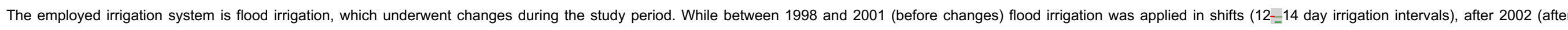

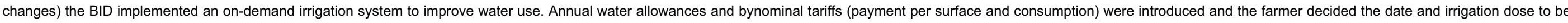
applied.

\section{3 Methodology}

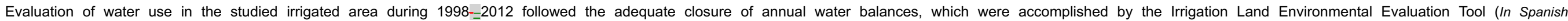
EvaluadorMedioambiental de Regadios--EMR; Causapé, 2009)

\subsubsection{Water balance}

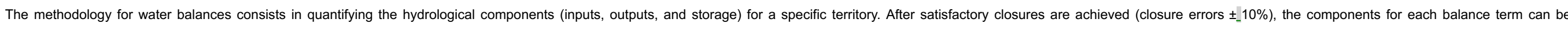

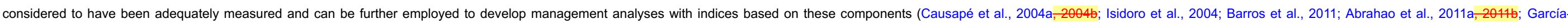
Garizábal et al., 2012a,2012b; Merchán et al., 2015).

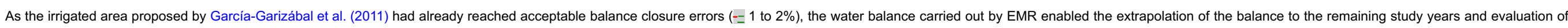
irrigation quality by indices. In this sense, the soil water balance equation was:

$(\mathrm{I}+\mathrm{P})-\left(\mathrm{ET}_{\mathrm{R}}+\mathrm{D}\right)=\mathrm{AW}$

where the inputs (irrigation, I and precipitation, $\mathrm{P}$ ) minus the outputs (evapotranspiration, $\mathrm{ET}_{\mathrm{R}}$ and drainage, $\mathrm{D}$ ) equals the variation of water in the soil (Available Water, AW).

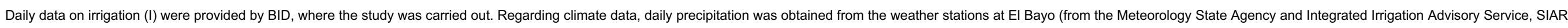




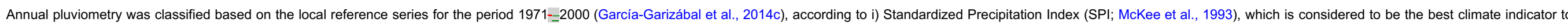

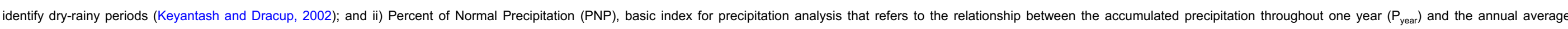
precipitation for a region in a given period $\left(\mathrm{P}_{1971-2000}\right)$ :

$\mathrm{PNP}(\%)=100 \cdot\left(\mathrm{P}_{\text {year }}-\mathrm{P}_{1971-2000}\right) / \mathrm{P}_{1971-2000}$

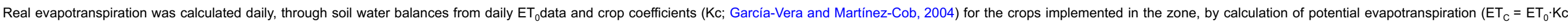
Allen et al., 1998).

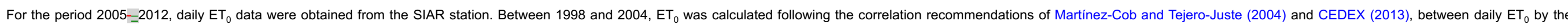
Hargreaves method and $E_{0}$ by the Penman-Monteith method (Allen et al., 1998), since the period 2005-2009 coincided for AEMET and SIAR stations.

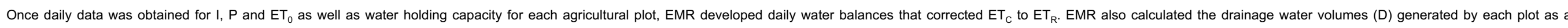
consequence of precipitation $\left(D_{P}\right)$ or irrigation $\left(D_{1}\right)$, along with the available useful water in the soil at the beginning $\left(A W_{\text {ini }}\right)$ and end $\left(A W_{\text {end }}\right)$ of each day.

\subsubsection{Irrigation Qquality lindices}

Net Hydric Needs (NHn), Irrigation Efficiency (IE) and Water Deficit (WD) were applied to evaluate water use in basin D-XIX-6. These indices were calculated from the results obtained by the water balance simulations carried out by EMR.

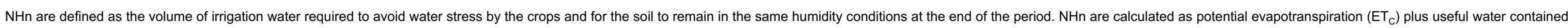
in the soil at the end $\left(A W_{\text {end }}\right)$ minus effective precipitation $\left(P_{\text {ef }}\right)$ and useful water in the soil at the beginning $\left(A W_{\text {ini }}\right)$.

$\mathrm{NHn}(\mathrm{mm})=\left(\mathrm{ET}_{\mathrm{C}}+\mathrm{AW}_{\text {end }}\right)-\left(\mathrm{P}_{\text {ef }}+\mathrm{AW}_{\text {ini }}\right)$

IE quantifies the irrigation percentage that has not been lost through drainage, and is calculated as one minus the relationship between drainage produced by irrigation and total irrigation volume applied:

$\mathrm{IE}(\%)=\left[1-\left(\mathrm{D}_{\mathrm{I}} / \mathrm{I}\right)\right] \cdot 100$

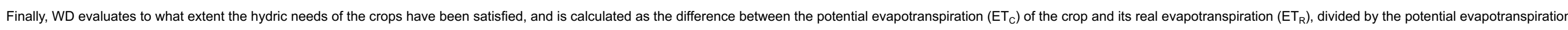
$\left(\mathrm{ET}_{\mathrm{C}}\right)$ of the crop:

$\left.\mathrm{WD}(\%)=\left[\left(\mathrm{ET}_{\mathrm{C}}-\mathrm{ET}_{\mathrm{R}}\right) / \mathrm{ET}_{\mathrm{C}}\right)\right] \cdot 100$

\subsubsection{Statistical calculations}

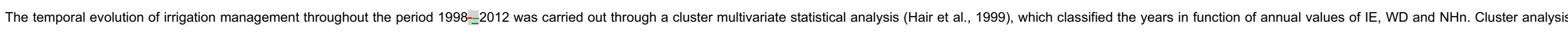
was accomplished with standardized data, using the Euclidean square distance as similarity measure. The Ward method was followed to obtain hierarchic conglomerates (Hair et al., 1999).

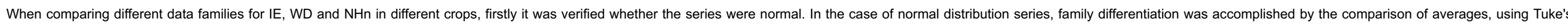

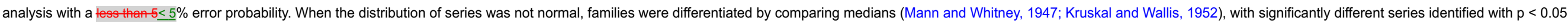

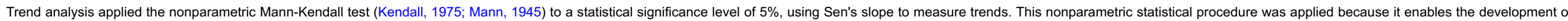
analyses without considering the probability distribution of the data employed, and is more permissible to the occurrence of extreme values or other discontinuities.

\subsection{Results and discussion}

\subsubsection{Water balance}

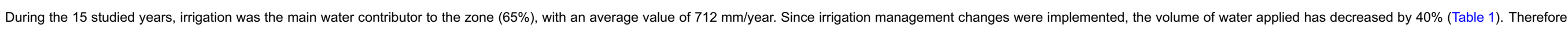
after implementation of on-demand irrigation, annual irrigation volumes have not surpassed the lowest annual irrigated volume in 1998--2001. 


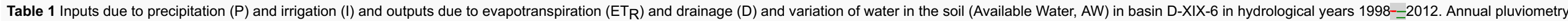
classification according to the Standardized Precipitation Index (SPI) and Percent of Normal Precipitation (PNP).

\section{alt-text: Table 1}

\begin{tabular}{|c|c|c|c|c|c|c|c|}
\hline SPI & $\begin{array}{c}\mathrm{PNP} \\
\%\end{array}$ & Year & $\underset{\mathrm{mm}}{\mathrm{P}}$ & $\begin{array}{c}\mathrm{I} \\
\mathrm{mm}\end{array}$ & $\begin{array}{l}\mathrm{ET}_{\mathrm{R}} \\
\mathrm{mm}\end{array}$ & $\underset{\mathrm{mm}}{\mathrm{D}}$ & $\frac{\mathrm{AWU}}{\mathrm{Mm}}$ \\
\hline$-\underline{-} 0,71$ & -15 & 1998 & 375 & 934 & 956 & 323 & \pm 29 \\
\hline $\pm 0,30$ & +3 & 1999 & 453 & 785 & 945 & 314 & $-=21$ \\
\hline$=-2,19$ & $=30$ & 2000 & 309 & 1127 & 1026 & 417 & $=7$ \\
\hline $\pm 0,60$ & +9 & 2001 & 482 & 1201 & 1116 & 526 & \pm 41 \\
\hline$-=1,15$ & $-=21$ & 2002 & 350 & 585 & 805 & 173 & $-=43$ \\
\hline $\pm 0,57$ & +9 & 2003 & 479 & 706 & 1000 & 179 & \pm 6 \\
\hline $\pm 1,38$ & +30 & 2004 & 581 & 708 & 1020 & 265 & \pm 3 \\
\hline$-=3,09$ & $-=49$ & 2005 & 226 & 611 & 824 & 70 & $=57$ \\
\hline $\pm 0,27$ & +2 & 2006 & $45 \underline{2} 3$ & 517 & 758 & 142 & \pm 71 \\
\hline$=0,76$ & $=16$ & 2007 & 372 & 539 & 776 & 178 & $=44$ \\
\hline$=2,34$ & $-=31$ & 2008 & 305 & 604 & 716 & 176 & \pm 16 \\
\hline$-=0,14$ & - \pm 6 & 2009 & 415 & 615 & 815 & 235 & $=20$ \\
\hline$-=1,36$ & $-=23$ & 2010 & 340 & 615 & 762 & 188 & \pm 5 \\
\hline$=2,64$ & $-=33$ & 2011 & 298 & 554 & 718 & 159 & $=24$ \\
\hline \multirow[t]{3}{*}{$=3,09$} & $-=63$ & 2012 & 165 & 573 & 640 & 75 & \pm 23 \\
\hline & & $98=12$ & 374 & 712 & 855 & 228 & $=1$ \\
\hline & & CV \% & 29 & 30 & 16 & 54 & 2307 \\
\hline $1998-=2012$ & & mm/year & -ב $10 \mathrm{~ns}^{\star}$ & $-=33 * *$ & $-25-* * *$ & $=18 * *$ & $=0,4 \mathrm{~ns}$ \\
\hline
\end{tabular}

Statistical significance: $\mathrm{ns}=$ not significant.

$*_{p_{-}}<0,05$.

$* * p_{-}<0,01$

$* * * p_{-}<0,-001$

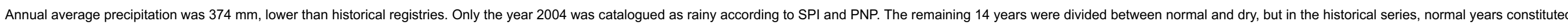

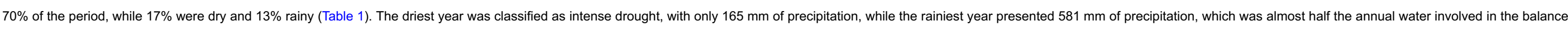
$(45 \%)$.

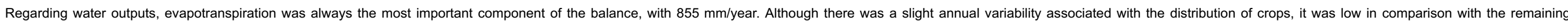
components of the balance. Therefore, the increase in winter cereal at the expense of alfalfa and corn resulted in $E T_{R}$ reduced by one third (Table 1).

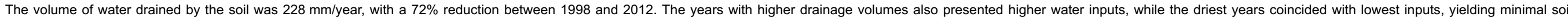




\subsubsection{Irrigation quality}

The NHn measured in the zone for the 15 studied years were $670 \mathrm{~mm} / \mathrm{year}$, and although the changes in crop distribution reduced the hydric needs by $8 \%$, this decrease was not significant.

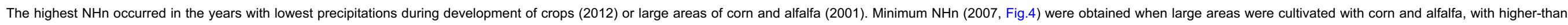
average precipitation.

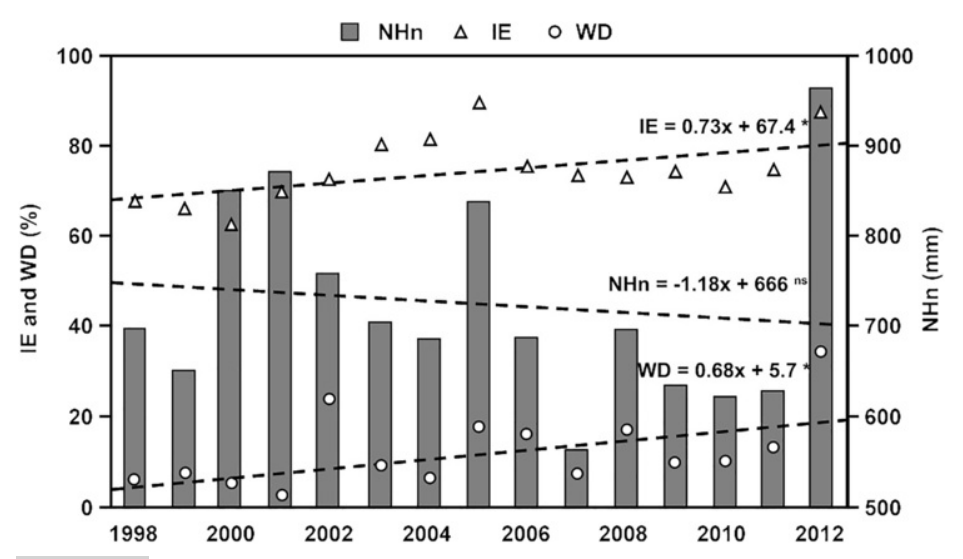

Figure-4.Fig. 4 Annual evolution of Irrigation Efficiency (IE), Water Deficit (WD) and Net Hydric Needs (NHn) in basin D-XIX-6, during 1998-_2012. The upper section indicates the slope values and statistical significance: $n s=$ not significant; ${ }^{*} \mathrm{p}_{\mathbf{1}}<0.05$. alt-text: Fig. 4

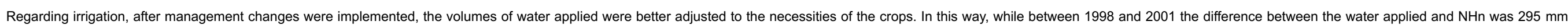
during the post-change period an average deficit of only $9 \mathrm{~mm}$ was recorded between April and September. Annual deficits ranged from $=153$ to $=357 \mathrm{~mm}$ in the dry years 2002,2005 , and 2012 .

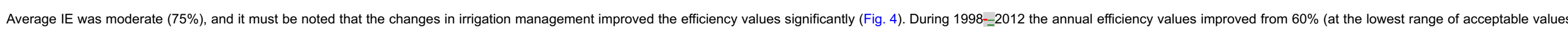

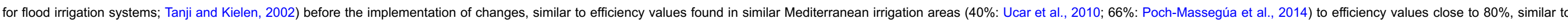

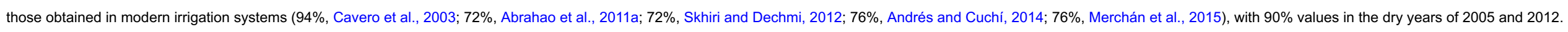

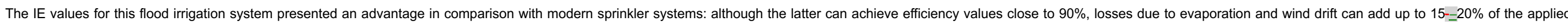
irrigation (Dechmi et al., 2003; Playán et al., 2005; Abrahao et al., 2011a; Merchán et al., 2015).

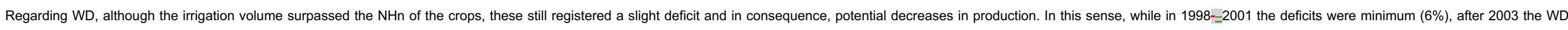
values were incremented by $15 \%$, reaching $35 \%$ in 2012 (driest year of the series), following a $0.7 \%$ /year trend (Fig. 4).

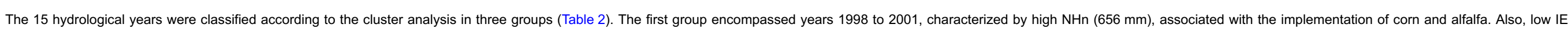
were obtained $(66 \%)$ along with WD $(6 \%)$, due to the impossibility of applying irrigation in the most adequate moment (conditioned to the traditional flood irrigation in shifts).

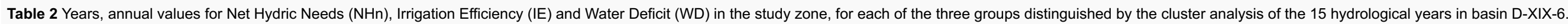
alt-text: Table 2

\begin{tabular}{|c|c|c|c|c|}
\hline Group & & 1 & 2 & 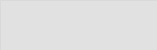 \\
\hline Years & & 1998, 1999, 2000, 2001 & 2002, 2003, 2004, 2006, 2007, 2008, 2009, 2010, 2011 & 2005, 2012 \\
\hline $\mathrm{NHn}$ & $\mathrm{mm} /$ year & 656 & 517 & 692 \\
\hline
\end{tabular}




\begin{tabular}{l|l}
$\%$ & 6
\end{tabular}

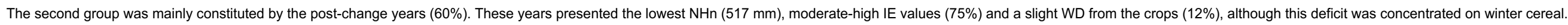

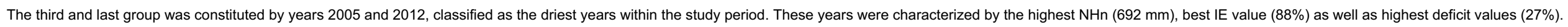
In this way, the years with highest IE also presented elevated WD values, and despite the fact that on-demand irrigation helped achieve better application efficiencies, it occurred at the expense of a slight increase in water deficit. Within 1998-=2012, no variations in the NHn of the crops were detected which could be associated with changes in irrigation management, and positive trends were observed for IE and WD.

\subsubsection{Monthly evaluation of irrigation quality}

Monthly NHn suffered important changes during the study period, and with the exception of September (no variations), NHn increased moderately in April and May and then decreased from June to August (Fig. 5).

- NHn

$\Delta$ IE

$\circ$ WD
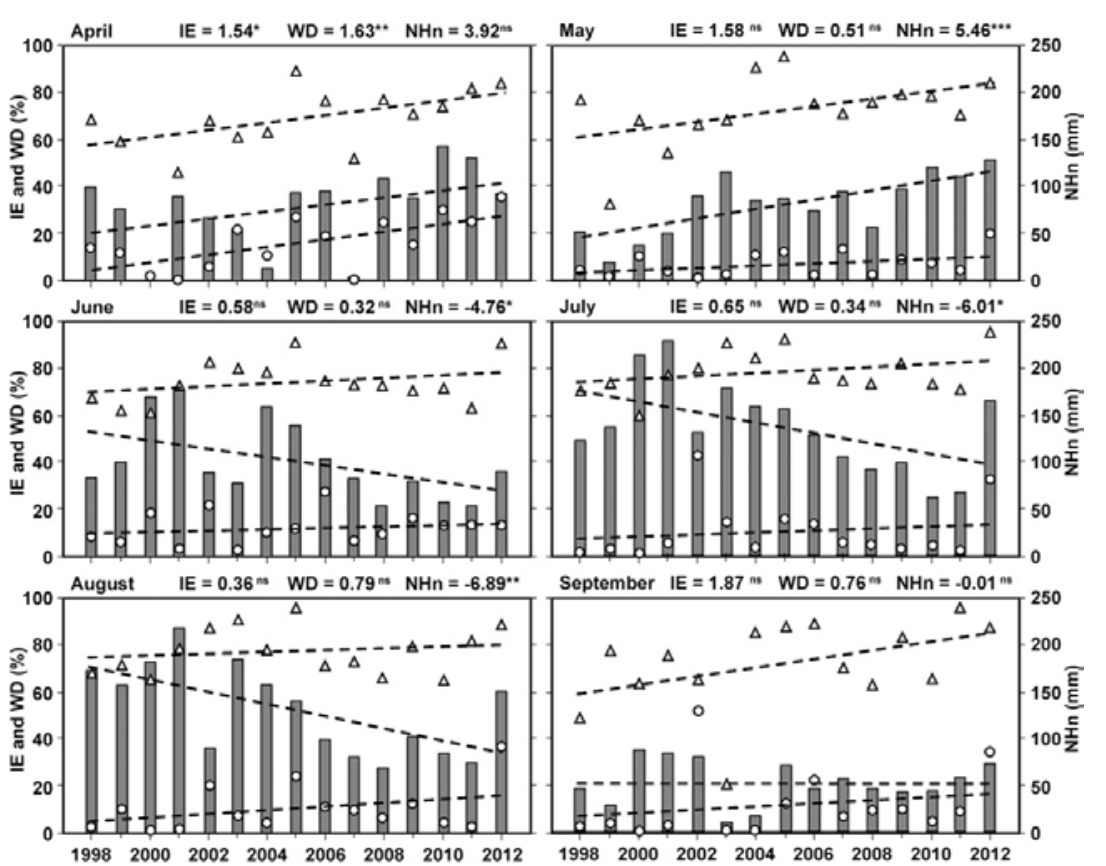

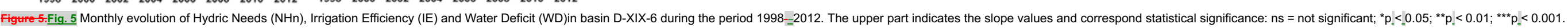
alt-text: Fig. 5

Such evolution is a consequence of the increase of winter cereal surface, with a growth cycle that extends from November to June, at the expense of corn and alfalfa surfaces, with a development cycle from April to September.

In this way, a greater extension of cultivable land had no occupation in the Summer months, when the implemented crops presented the highest Kc and maximum evapotranspirative demands, reducing NHn from June to August.

Regarding IE, all months presented positive trends, with annual increment rates close to $2 \%$ in April, May and September, significantly superior to the Summer months, which did not surpass $1 \%$ annually (Fig. 5).

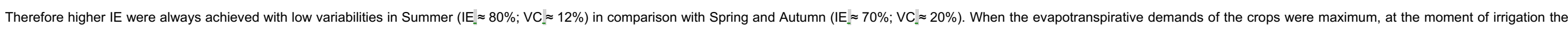
soil was closer to its wilting point, and IE improvements resulted minimal. 
The increases in efficiency values were maximum at the beginning and end of the irrigation campaign, when better water control enabled a better adjustment between the lowest hydric needs of the crops and the irrigation applied.

Regarding WD, although the monthly irrigation volumes applied surpassed the hydric needs of the crops, slight deficit values were registered (under $8 \%$ ), except for the months of April and June.

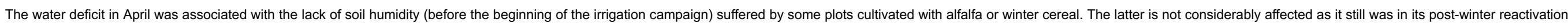
process.

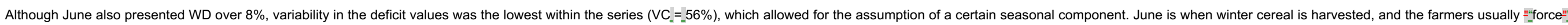
a slight deficit in this crop to favor the drying previous to harvesting.

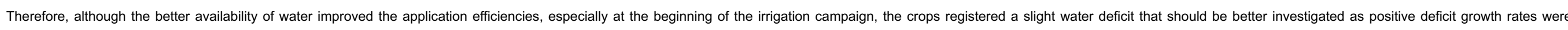
obtained during the study period.

\subsubsection{Irrigation quality indices per crop}

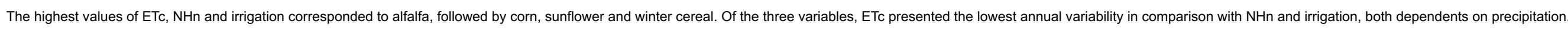

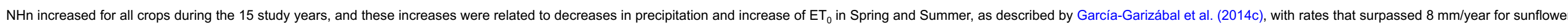
and alfalfa (Fig. 6).

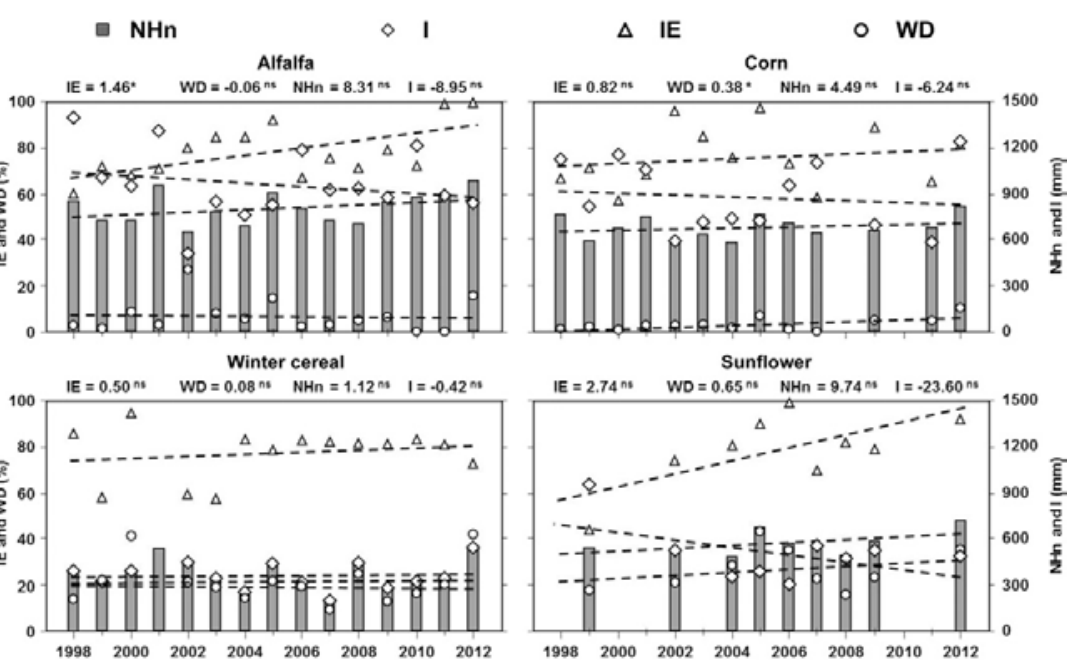

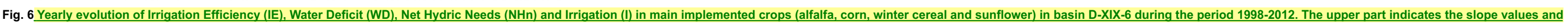
correspond statistical significance: $n s=$ not significant; ${ }^{*} p<0.05 ; * * p<0.01 ; * * * p<0.001$.

alt-text: Fig. 6

The irrigation applied decreased for all crops, with the most affected being sunflower $(-=24 \mathrm{~mm} / \mathrm{year}$ ) and alfalfa (- $-9 \mathrm{~mm} / \mathrm{year})$, in comparison with corn and winter cereal, with decreases of only $-=1 \mathrm{~mm} / \mathrm{year}$ (Fig. 6).

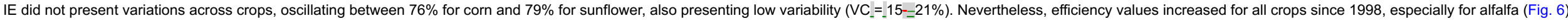
Winter cereal was the crop that suffered the least changes in efficiency values, with a low improvement in IE $(0.4 \%)$, while sunflower benefitted the most, with annual improvements close to $3 \%$.

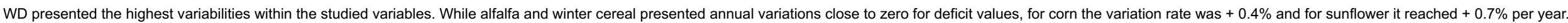

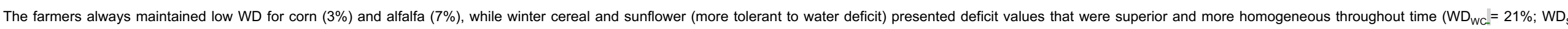




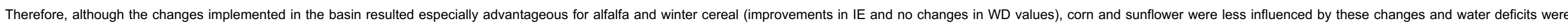
detected and should be conveniently addressed.

\subsection{Conclusions}

Implementation of changes in water management at the studied irrigation area contributed to a reduction in the volumes of irrigation applied (40\%) and in drainage $(72 \%)$.

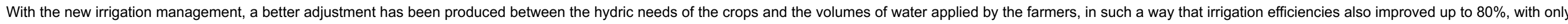
a slight increment of water deficit.

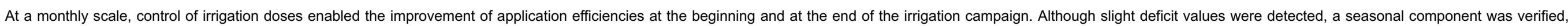
associated with the management by farmers.

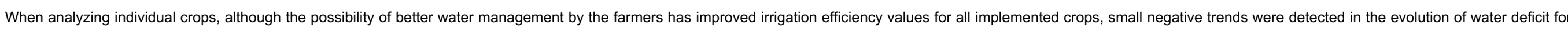
corn and sunflower, which should be improved.

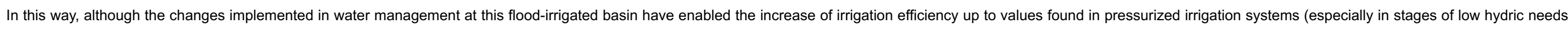
as it allows for a better adjustment between water demands and applied doses), specific episodes of water deficits still occur, which should be remediated.

\section{Acknowledgments}

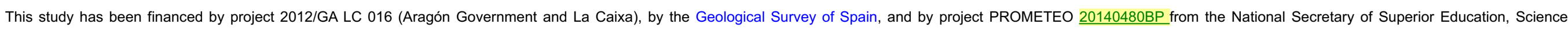
Technology and Innovation (SENESCYT)

\section{References}

Abrahao R., Causapé J., Garcia-Garizabal I. and Merchán D., Implementing irrigation: water balances and irrigation quality in the Lerma Basin (Spain), Agric. Water Manage.Agric. Water Manaq. 102, 2011 a, 97-104.

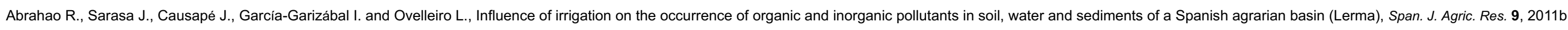

124-134.

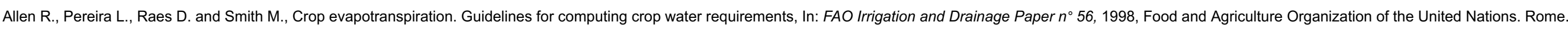

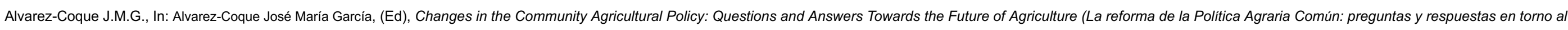

futuro de la agricultura), 2006, Ministerio de Agricultura, Alimentación y Medio Ambiente-Eumedia; Madrid.

Andrés R. and Cuchí J.A., Analysis of sprinkler irrigation management in the LASESA district, Monegros (Spain), Agric. Water Manag. 131, 2014, 95-107, http://dx.doi.org/10.1016/j.agwat.2013.09.016.

Barros R., Isidoro D. and Aragüés R., Long-term water balances in La Violada Irrigation District (Spain): I. Sequential assessment and minimization of closing errors, Agric. Water Manag. 102, 2011, 35-45.

Bustos A., Caballero R. and Roman R., Net changes of main ions in the soil profile of irrigated field plots in central Spain, Irrig. Sci. 25, 2006, 1-9.

Caballero R., Bustos A. and Roman R., Soil salinity under traditional and improved irrigation schedules in central Spain, Soil Sci. Soc. Am. J. 65, 2001, 1210-1218.

Causapé J., A computer-based program for the assessment of water-induced contamination in irrigated lands, Environ. Monit. Assess. 158, 2009, 307-314, http://dx.doi.org/10.1007/s10661-008-0584-Z.

Causapé J., Quilez D. and Aragüés R., Assessment of irrigation and environmental quality at the hydrological basin level—I. Irrigation quality, Agric. Water Manag. 70, 2004a, 195-209.

Causapé J., Quilez D. and Aragüés R., Assessment of irrigation and environmental quality at the hydrological basin level—II. Salt and nitrate loads in irrigation return flows, Agric. Water Manag. 70, 2004b, 211-228. 
Cavero J., Beltrán A. and Aragüés R., Nitrate exported in the drainage water of two sprinkler irrigated watershed, J. Environ. Qual. 32, $2003,916-926$.

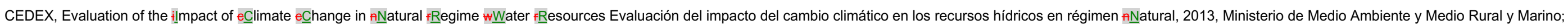
Madrid.

Dechmi F., Playán E., Cavero J., Faci J.M. and Martinez-Cob A., Wind effects on solid set sprinkler irrigation depth and yield of maize (Zea mays), Irrig. Sci. 22, $2003,67-77$.

Diaz RJR.J., Overview of hypoxia around the world, J. Environ. Qual. 30, 2001, 275-281.

Duncan R.A., Bethune M.G., Thayalakumaran T., Christen E.W. and McMahon T.A., Management of salt mobilisation in the irrigated landscape. A review of selected irrigation regions, J. Hydrol. 351, 2008, 238-252.

FAO, Unlocking the Water Potential of Agriculture, 2003, Food and Agriculture Organization of the United Nations, (http://www.fao.org/DOCREP/006/Y4525S/Y4525S00.HTM (accessed 01.05.16)).

FAO, Agricultural Outlook 2006-_2015, 2006, Food and Agriculture Organization of the United Nations, (ftp://ftp.fao.org/docrep/fao/009/a0621e/a0621e00.pdf (accessed 01.05.16)).

Feng Z.Z., Wang X.K. and Feng Z.W., Soil N and salinity leaching after the autumn irrigation and its impact on groundwater in Hetao Irrigation District, China, Agric. Water Manag. 71, 2005, 131-143.

García-Garizábal I. and Causapé J., Influence of irrigation water management on the quantity and quality of irrigation return flows, J. Hydrol. 385, 2010, 36-43.

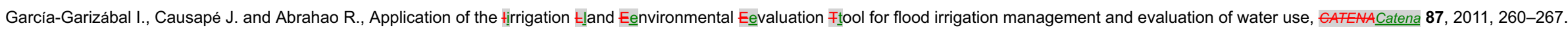

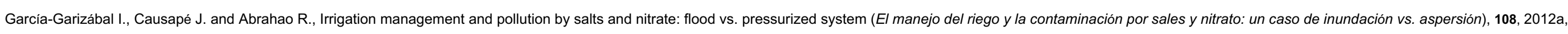
ITEA, 1-19.

García-Garizábal I., Causapé J. and Abrahao R., Nitrate contamination and its relationship with flood irrigation management, J. Hydrol. 442, $2012 \mathrm{~b}, 15-22$.

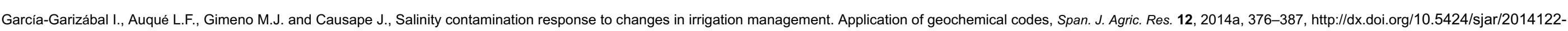
4694.

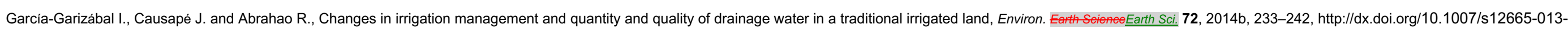
2949-z.

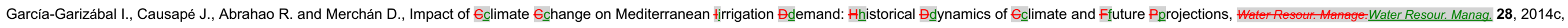
1449-1462, http://dx.doi.org/10.1007/s11269-014-0565-7.

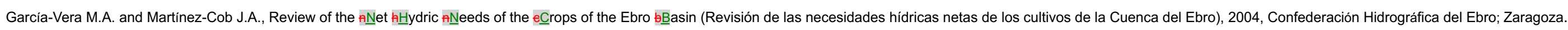
Gehl R.J., Schmidt J.P., Stone L.R., Schlegel A.J. and Clark G.A., In situ measurements of nitrate leaching implicate poor nitrogen and irrigation management on sandy soils, J. Environ. Qual. 34, 2005, 2243-2254.

Gkiougkisa I., Kalliorasb A., Pliakasa F., Pechtelidisa A., Diamantisa V., Diamantisa I., Ziogasa A. and Dafnisa I., Assessment of soil salinization at the eastern Nestos River Delta, N.E. Greece, Catena 128, 2015, 238-251, http://dx.doi.org/10.1016/j.catena.2014.06.024.

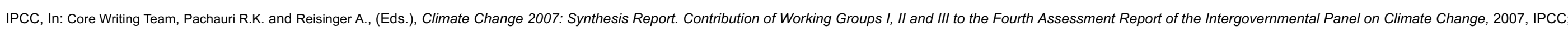
Geneva.

IPCC, Climate $\in \underline{C}$ hange and $w \underline{W}$ ater, 2008, Cambridge University Press; Cambridge.

Isidoro D., Quilez D. and Araguées R., Water balance and irrigation performance analysis: La Violada irrigation district (Spain) as a case study, Agric. Water Atage.Agric. Water Manaq. 64, $2004,123-142$.

Isidoro D., Quilez D. and Aragüés R., Environmental impact of irrigation in La Violada District (Spain): I. Salt export patterns, J. Environ. Qual. 35, $2006,766-775$.

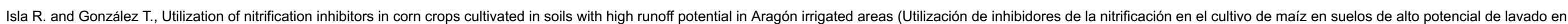


regadios de Aragón), 2006, XI Simposio Ibérico sobre Nutrición mineral de las Plantas; Pamplona.

Kendall M.G., Rank $€$ Correlation method, 1975, Griffin; London.

Keyantash J. and Dracup J., The quantification of drought: an evaluation of drought indices, Bull. Am. Meteorol. Soc. 83, 2002, 1167-1180.

Kruskal W.H. and Wallis W.A., Use of ranks in one-criterion variance analysis, J. Am. Stat. Assoc. 47, 1952, 583-621.

Lecina S., Playán E., Isidoro D., Dechmi F., Causapé J. and Faci J.M., Irrigation evaluation and simulation at the irrigation Đdistrict V of Bardenas (Spain), Agric. Water Manage.Agric. Water Manag. 73, 2005, 223-245.

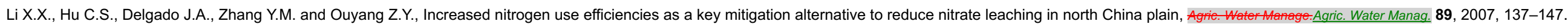

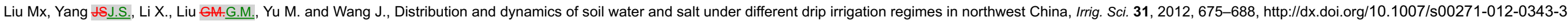

Mann H.B., Nonparametric test against trend, Econometrica 13, 1945, 245-259.

Mann H.B. and Whitney D.R., On a test of whether one of two random variables is stochastically larger than the other, Ann. Math. Stat. 18 (1), 1947, 50-60.

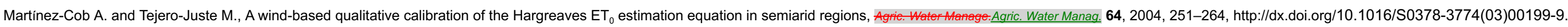

McKee T.B.N., Doesken J. and Kleist J., The relationship of drought frequency and duration to time scales. Eight conference on applied climatology, Am. Meteorol. Soc. 1993, 179-184, (Anaheim, CA).

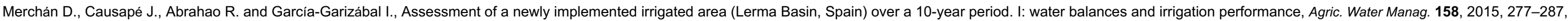
http://dx.doi.org/10.1016/j.agwat.2015.04.016.

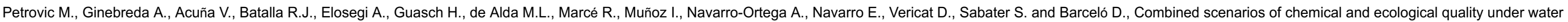
scarcity in Mediterranean rivers, TrAC Trends Anal. Chem. 30, 2011, 1269-1278.

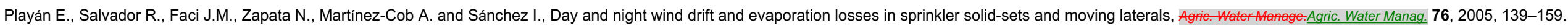

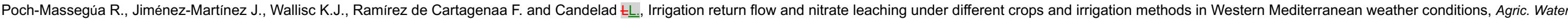
Manag. 134, 2014, 1-13, http://dx.doi.org/10.1016/j.agwat.2013.11.017.

Roman R., Caballero R. and Bustos A., Field water drainage under traditional and improved irrigation schedules for corn in central Spain, Soil Sci. Soc. Am. J. 63, $1999,1811-1817$.

Scavia D. and Bricker S.B., Coastal eutrophication assessment in the United States, Biogeochemistry 79 (1_2), 2006, 187-208.

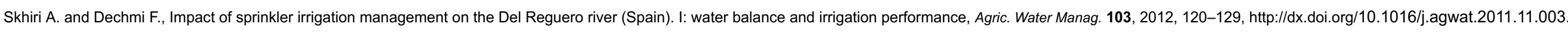

Spalding R.F., Watts D.G., Schepers J.S., Burbach M.E., Exner M.E., Poreda R.J. and Martin G.E., Controlling nitrate leaching in irrigated agriculture, J. Environ. Qual. 30, 2001 , 1184-1194.

Tanji K.K. and Kielen N.C., Agricultural drainage water management in arid and semi-arid areas, In: FAO Irrigation and Drainage Paper $n^{\circ} 61$, 2002, Food and Agriculture Organization of the United Nations. Rome.

Tedeschi A., Beltrán A. and Aragüés R., Irrigation management and hydrosalinity balance in a semi-arid area of the middle Ebro river basin (Spain), Agrie. Wateragagric. Water Manag. 49, 2001, 31-50.

Thayalakumaran T., Bethune M.G. and McMahon T.A., Achieving a salt balance should it be a management objective?, Agric. Water Manag. 92, 2007, 1-12, http://dx.doi.org/10.1016/j.agwat.2007.05.004.

Thayalakumaran T., Bristow K.L., Charlesworth P.B. and Fass T., Geochemical conditions in groundwater systems: implications for the attenuation of agricultural nitrate, Agric. Water Manag. 95, 2008, 103-115,

http://dx.doi.org/10.1016/j.agwat.2007.09.003.

Ucar Y., Senyigit U., Kadayifci A. and Tuylu G.I., Evaluation of water use efficiency at parcel and scheme levels: Aa case study of Sarkikaraagac irrigation scheme in Turkey, J. Food Agric. Environ. 8, 2010, 1046-1053.

Wang B., Cultural eutrophication in the Changjiang (Yangtze River) plume: Hhistory and perspective, Estuar. Coast. Shelf Sci. 69, 2006, 471-477. 
- The investigation includes long-term monitoring throughout 15 hydrological years.

- Changes contributed to improve irrigation efficiency and drainage reduction.

- Water deficit episodes were detected that should be remediated.

\section{Queries and Answers}

Query:

Please provide caption

Answer: Caption has been added. Thank you.

Query:

Please check the layout and presentation of Tables 1 and 2 if correct.

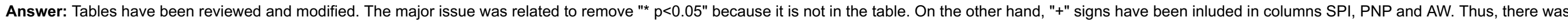
a typewriting mistake in $\mathrm{P}$ in year 2006, and the corect vale is 452 . Thank you.

Query:

Footnote "*" was not cited in Table 1. Hence, a dummy footnote citation was added here. Please check for proper placement and amend as necessary.

Answer: OK, If necessary, remove de line below "* $p<0,05$ " because "*" is not used in table 1 . Thank you.

Query:

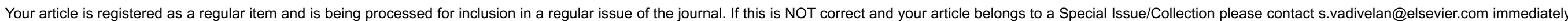
prior to returning your corrections.

Answer: The article is a regular item. Thank you.

Query:

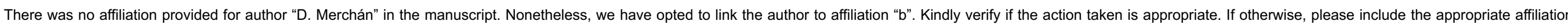
along with the corrections. Thank you.

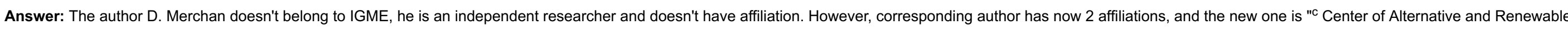
Energy, Department of Renewable Energy Engineering, Federal University of Paraiba, Cx Postal 5115, 58051-900, João Pessoa, Paraíba, Brazil" 
The author names have been tagged as given names and surnames (surnames are highlighted in teal color). Please confirm if they have been identified correctly

Answer: Author names were identified correctly. Thank you.

Query:

Please check whether the designated corresponding author is correct, and amend if necessary.

Answer: The corresponding author is correct. Thank you.

Query:

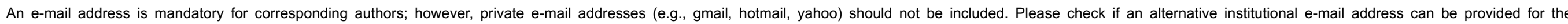
corresponding author/s.

Answer: ikerggarizabal@gmail.com

Query:

Please check the hierarchy of the section headings and confirm if correct.

Answer: It is correct. Thank you.

Query:

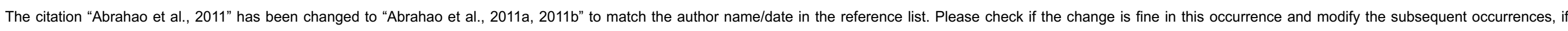
necessary.

Answer: Abrahao et al., 2011 is Abrahao et al., 2011a

Query:

The citation "Causapé et al., 2004" has been changed to "Causapé et al., 2004a, b" to match the author name/date in the reference list. Please check if the change is fine in this occurrence.

Answer: Causapé et al., 2004 is Causapé et al., 2004a

Query:

The citation "Garcia-Garizábal et al., 2012" has been changed to "García-Garizábal et al., 2012a, b" to match the author name/date in the reference list. Please check if the change is fine in this occurrence.

Answer: García-Garizábal et al., 2012 is García-Garizábal et al., 2012a

Query:

Citation "Hair et al., 1999" has not been found in the reference list. Please supply full details for this reference.

Answer: Hair, J., Anderson, R., Tatham, R., Black, W., 1999. Análisis multivariante, fifth ed, Prentice Hall Iberia, Madrid.

Query:

Please provide the corresponding grant number(s) for the following grant sponsor(s): "Geological Survey of Spain" and "SENESCYT".

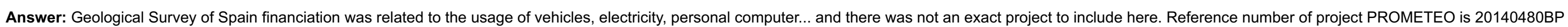

